\title{
Preservice Teachers' Personality Traits and Social Network Use Purposes
}

\author{
Ferit Karakoyun \\ Dicle University, Turkey \\ ORCID: 0000-0003-1110-4035
}

Received: 19.06.2019

Accepted: 23.09.2019

Published: 16.10 .2019

\begin{abstract}
Facilities provided by social network sites allow individuals to use social networks for various purposes such as communication, entertainment and information sharing. These purposes vary depending on the social networks individuals use and on their personality traits. The present study examined preservice teachers' social network use purposes with respect to their personality traits. The participants of the study were 660 preservice teachers attending a Turkish university. For data collection in the study "Scale of Social Network Use Purposes" and "Basic Personality Traits Inventory" were used. The research data were analyzed using Pearson Correlation Analysis and Multi-Linear Regression Analysis. The findings revealed that among the personality traits, conscientiousness, openness to experience and negative valence were predictors of the sub-factors of social network use purposes. As for other personality factors, neuroticism and extraversion were not significant predictors of the total social network use purpose score or its sub-factors.
\end{abstract}

Keywords: Social network sites; Social media; Personality; Five-Factor Model; Preservice teachers

\section{Introduction}

The Internet was first developed as a platform that allowed people to reach information (Hamburger \& Ben-Artzi, 2000). Later, with developments in Internet technologies, Web 2.0 appeared, and thanks to the dynamic structure provided by this technology, Internet users have become individuals producing information rather than just obtaining the information. Today, it is possible and fairly easy for Internet users to produce and share content even without any knowledge of programming (O'Reilly \& Milstein, 2009). The Web 2.0 technology led to the development of tools such as video sharing sites and blogs, which allow users to establish communication with others, to socialize with acquaintances, to expand their communication network and to share information (Ellison, Steinfield, \& Lampe, 2007; Jones \& Fox, 2009). Another important facility provided by this technology concerns the social network sites (SNS), which allow social interaction and online transfer of information (Boyd \& Elison, 2007).

\section{Social Network Sites}

Social networks are among the most common tools provided by the Internet. In a report published by the Social Media Agency of WeAreSocial in January 2018, it was revealed that there 
were 4,021 billion Internet users throughout the world and that 3,196 billion people were active users of social networks (Kemp, 2018). Social network sites (SNS) are web-based services that provide individuals with the opportunity to create their own profiles within a certain framework, to form a list of other users they will share a connection with, to navigate within their list of connections and to view what others share in the system (Boyd \& Ellison, 2007). Hughes, Rowe, Batey, and Lee (2012) define SNSs as virtual collections of user profiles that can be shared by other users. Most activities found in a SNS are in the form of viewing and posting thoughts, questions, responses, photos, videos and personal information with the use of the connectivity provided by the network platform. Therefore, viewing (passive network use) and posting (active network use) are two fundamental elements of any virtual social network. Posting also allows viewing, while the latter mostly triggers the former. In this way, successful SNS support the prolific cycle of content creation and its consumption by many users (Pagani, Hofacker, \& Goldsmith, 2011).

SNSs, which are regarded as new tools to create an identity and which allow individuals to define and express themselves freely (Mehdizadeh, 2010), are used for various purposes such as communicating with friends and family members, getting introduced to new people (Boyd \& Ellison 2007; Ellison, Steinfield, \& Lampe, 2007; Lee, Chou, \& Huang, 2014), accessing and sharing information (Kim, Jeong, \& Lee, 2010), forming online communities (Lee, Chou, \& Huang, 2014) and entertaining (Lin, Hoffman, \& Borengasser, 2013). All these purposes also vary based on the SNS used by individuals and on the time they spend in these networks as well as on their personality traits (Cetin, 2008; Isbulan, 2011; Yilmaz \& Bilgin, 2017).

\section{Personality Traits}

Personality is the whole of innate traits which are shaped in line with individuals' interaction with the environment and which help distinguish one person from another (McCrea \& Costa, 2003). When related literature is examined, it is seen that there are a wide variety of views about the concept of personality. On the other hand, it could be stated that the Five-Factor Model has a more integrative framework and that it is widely used in literature. According to the Five-Factor Model, personality traits include five sub-dimensions: extraversion, neuroticism, agreeableness, openness to experience and conscientiousness (Goldberg, 1990; McCrea \& Costa, 2003). In addition, in one study carried out by Gencoz and Oncul (2012) in Turkey, a new dimension called "negative valence", which is specific to the Turkish culture, was added to the five factors found in the Five-Factor Model.

When each of the sub-dimensions of personality found in the Five-Factor Model was examined, it was seen that extravert people are energetic individuals who enjoy spending time with others and who are friendly, impressive and dominant in social environments (Costa \& McCrae, 1992). When neuroticism personality trait is considered, it could be stated that individuals with this trait are more likely to have negative feelings and to experience psychological problems and that they tend to fail to cope with negative feelings (Caspi, Roberts, \& Shiner, 2005). Regarding the personality trait of agreeableness, individuals belonging to this group are more likely to demonstrate more flexible attitudes and are more prominent with such characteristics as being kind, considerate, cooperative and having a high capability of self-control (Caspi, Roberts, \& Shiner, 2005; McCrea \& Costa, 2003). People with high levels of openness to experience are individuals who are open to changes and innovations both in intellectual and in experimental respects, who have a high tendency to get involved in adventures, who consider alternative approaches to a certain situation and who are prominent with their curiosity and creativity 
(Caspi et al., 2005). In relation to conscientiousness, people with this personality trait are thought to be reliable, hardworking, prudent, cautious, responsible, organized, disciplined and eager to achieve (Funder, 2001; McCrea \& Costa, 2003). As for negative valence personality trait mentioned in the study carried out by Gencoz and Oncul (2012) refers to such negative selfdirected attributions as mannered, pretentious, backstabbing and rude.

\section{SNSs and Personality Traits}

SNS use purposes of individuals could be said to be influenced by a number of factors. One of these factors is related to the personality traits of individuals. In most studies investigating the relationships between relationships of individuals' personality traits with their attitudes in SNSs like Facebook and Twitter as well as with their motivations and purposes of using these SNSs, the personality traits were examined using the measurement tools based on the Five-Factor Model (Gosling et al., 2011; Seidman, 2013; Wehrli, 2008).

An overall review of the studies conducted using the Five-Factor Model revealed three personality traits that are important in terms of SNS use: extraversion, openness to experience and neuroticism (Correa, Hinsley, \& Zuniga, 2010; Ross, Orr, Sisic, Arseneault, Simmering, \& Orr, 2009; Zywica \& Danowski, 2008). In one study, Ross et al. (2009) found that extravert university students have a tendency to become members of more Facebook groups and that individuals open to experience are more likely to use Facebook to socialize. In addition, it was seen that neurotic individuals use SNSs mostly for communication purposes (Correa et al., 2010; Ehrenberg, Juckes, White, \& Wals, 2008; Wolfradt \& Doll, 2001), while university students open to experience send more posts to other SNS users' walls (Ross et al., 2009). Although these three personality traits were prominent in studies examining the relationships between SNSs and personality, there are some other studies demonstrating that other traits of personality have a relationship with SNS use (Alan \& Kabadayi, 2016; Amichai-Hamburger \& Vinitzky, 2010; Avcilar \& Demirgunes, 2016; Seidman, 2013).

\section{SNS in Education}

When studies on the use of SNSs for educational purposes were examined, it was seen that Kumar and Vigil (2011) found a great gap between the preservice teachers' low level of use Web 2.0 tools for educational purposes and their high level of use of these tools for personal activities. In addition, the preservice teachers rarely took part in the development of educational online content. Sendurur, Sendurur, and Yilmaz (2015) pointed out that preservice teachers mainly used SNSs to meet their communication needs. Other reasons included obtaining information about the school and sharing information. In another study, Staines and Lauchs (2013) stated that SNSs could generally be defined as a means for students' socialization and that use of SNSs for academic purposes constitutes only a small proportion of overall SNS use purposes.

Researchers put emphasis on the positive effects of SNSs on teachers' professional development (Ranieri, Manca, \& Fini, 2012). Other studies demonstrated that social network tools support educational activities by allowing interaction, cooperation, active participation, critical thinking and sharing information and sources (Mazman \& Usluel, 2010). On the other hand, when studies conducted with university students in relation to personality and SNS use were examined, it was seen that SNS use purposes are likely to change depending on the personality traits. In this 
respect, the personality traits of preservice teachers may have influence on the use of SNS in educational setting. Therefore, it is important to examine preservice teachers' personality traits and the relationship of these traits with SNS use. Furthermore, most of the related studies were carried out with university students, and there is almost no research focusing on preservice teachers' SNS use purposes with respect to their personality traits (Atabek, 2012). For this reason, the present study is expected to contribute to the literature on preservice teachers' SNS use. In this respect, the purpose of the study was to examine preservice teachers' SNS use purposes in terms of their personality traits.

In line with this purpose, the sub-problems of the study were as follows: Is there a significant relationship between the personality trait sub-factors and the sub-factors of SNS use purpose? Do personality trait sub-factors predict the sub-factors of SNS use purpose?

In line with the related literature, the following hypotheses were formed within the frame of the research purposes;

H1. Conscientiousness predicts SNS use purposes.

H2. Openness to experience predicts SNS use purposes.

H3. Agreeableness predicts SNS use purposes.

H4. Negative valence predicts SNS use purposes.

H5. Extraversion predicts SNS use purposes.

H6. Neuroticism predicts SNS use purposes.

\section{Method}

\section{Research Model}

In the present study, the relational survey model, one of descriptive survey models, was used to examine the effects of preservice teachers' personality types on their SNS use purposes. The relational survey model is a research model that aims to determine the existence and/or degree of change between two or more variables (Karasar, 2005).

\section{Participants}

The participants of the study were 660 university students from Ziya Gokalp Faculty of Education of Dicle University. While determining the participants, the convenience sampling method, one of purposeful sampling methods, was used. Purposeful sampling allows conducting in-depth research by selecting_cases rich in information as appropriate to the research purposes (Buyukozturk et al., 2012). The convenience sampling method makes data collection process rapid and easy for the researcher. The researcher selects a case easy for him or her to access (Yildirim \& Simsek, 2005).

Of all the participants constituting the research sample, 469 of them were female (71\%), and 191 of them were male (29\%). It was seen that the participants mostly connected to Instagram (41\%), which was followed by YouTube (16\%) and Facebook (12\%). In addition, the participants mostly spent $1-3$ hours (42\%) and 4-6 hours (33\%) on the Internet. 


\section{Measures}

In the study, for the purpose of measuring the personality traits of the participants, the Basic Personality Traits Inventory developed by Gencoz and Oncul (2012) and the Scale of SNS Use Purposes developed by Usluel, Demir, and Cinar (2014) were used.

In the present study, the six-factor Basic Personality Traits Inventory developed based on the five-factor Personality Model scales developed by Gencoz and Oncul (2012) was used because it was developed as appropriate to the Turkish culture. In addition, there are a few other scales developed to measure SNS use purposes in Turkey. However, as the sub-dimensions of the SNS use purposes scale developed by Usluel, Demir, and Cinar (2014) were appropriate to the purpose of the study, this scale was used in the present study

\section{Basic Personality Traits Inventory}

This scale, which was developed depending on the Five-Factor Model by Gencoz and Oncul (2012), included 45 adjectives, and it was based on self-report. In addition, a new dimension named "negative valence", which is specific to the Turkish culture, was added to the factors found in the Five-Factor Model. Negative valence is a sub-dimension including negative personality traits of a person (such as mannered, pretentious, backstabbing and rude). The scale was rated using five-point rating ( $1=$ I strongly disagree, 2 = I disagree, $3=$ I am neutral, 4= I agree, $5=1$ strongly agree). Among the scale items, eight of them were reversely scored (Item numbers: $6,7,21,22,24,32,38$ and 39). A high score to be received from any sub-dimension of the scale showed that the related personality trait was prominent in the person. The internal consistency coefficients of the scale were calculated as .89 for extraversion, .85 for agreeableness, .85 for conscientiousness, .60 for openness to experience, .83 for neuroticism and .71 for negative valence. The test-retest reliability values were found to be .84 for extraversion, .71 for agreeableness, .80 for conscientiousness, .83 for openness to experience, .81 for neuroticism and .72 for negative valence. For the validity of the inventory, construct validity, convergent validity, divergent validity and discriminant validity were tested. The results of the analyses revealed that the scale was reliable and valid and appropriate to Turkish culture.

\section{Scale of SNS Use Purposes}

The Scale of SNS Use Purposes was developed by Usluel, Demir, and Cinar (2014) to determine participants' SNS use purposes. The 7-point Likert-type scale was made up of 26 items. The scale included seven factors: research, cooperation, initiating communication, establishing communication, maintaining communication, sharing content and entertainment. The participants' responses to the scale items ranged between "I strongly disagree" (1) and "I strongly agree" (7). A high mean score to be received for any of the factors shows that the individual uses SNSs for the related purpose. The Cronbach alpha reliability coefficient of the scale was calculated as .92. The reliability coefficient calculated for the present study was .90 .

\section{Procedures}

Before the application, the students were informed about the purpose and importance of the study. Following this, the students were asked to fill in the Basic Personality Traits Inventory and 
the SNS Use Purposes Scale designed in the form of questionnaire. It took the participants to fill in the measurement tools about 15-20 minutes. Initially, a total of 685 questionnaires were distributed to the students, yet 25 of them were not included in the study because some of them were not filled in appropriately and/or completely. Eventually, the data collected from 660 students were included in the analysis.

\section{Data Analysis}

For the analysis of the data collected in the study, besides descriptive statistics, Pearson ProductMoment Correlation Analysis was conducted to examine the relationships between the participants' SNS use purposes and the sub-factors of basic personality traits, and Multi-Linear Regression Analysis was applied for the personality traits' prediction of SNS use purposes. For the analysis of the data, the significance level was taken as 0,05 , and the statistical package software of SPSS 20.0 was used.

\section{Results}

\section{Pearson Correlation Analysis}

Table 1 presents the results of Pearson Correlation Analysis between SNS use purposes and the sub-dimensions of basic personality traits.

Table 1. Pearson Correlation Analysis between SNS Use Purposes and the Sub-Dimensions of Basic Personality Traits

\begin{tabular}{|c|c|c|c|c|c|c|c|c|c|c|c|c|}
\hline & 1 & 2 & 3 & 4 & 5 & 6 & 7 & 8 & 9 & 10 & 11 & 1213 \\
\hline 1.Research & 1 & & & & & & & & & & & \\
\hline 2.Cooperation & $.41 * *$ & 1 & & & & & & & & & & \\
\hline$n^{3 . \text { Initiating }}$ & $-.10 * *$ & $.26 * *$ & 1 & & & & & & & & & \\
\hline $\begin{array}{l}\text { 은4.Establishing } \\
\text { a communication }\end{array}$ & $.21 * *$ & $.42 * *$ & $.19 * *$ & 1 & & & & & & & & \\
\hline $\begin{array}{l}\text { S } 5 . \text { Maintaining } \\
\text { 乞 communication }\end{array}$ & $.19 * *$ & $.47 * *$ & $.40 * *$ & $\begin{array}{l}.54^{*} \\
*\end{array}$ & & & & & & & & \\
\hline え 6.Content sharing & $.14^{* *}$ & $.45 * *$ & $.43^{* *}$ & $\begin{array}{l}.31^{*} \\
*\end{array}$ & $.52 * *$ & 1 & & & & & & \\
\hline 7.Entertainment & $.13^{* *}$ & $.30 * *$ & $.33^{* *}$ & $\begin{array}{l}.35^{*} \\
*\end{array}$ & $.46^{* *}$ & $\begin{array}{l}.53^{*} \\
*\end{array}$ & & & & & & \\
\hline 8.Extraversion & $.12 * *$ & $.11 * *$ & $-.09 *$ & .06 & .02 & $.08^{*}$ & * -.02 & 1 & & & & \\
\hline 9.Agreeableness & $.17^{* *}$ & $.20 * *$ & $-.12 * *$ & $.11^{*}$ & $.11^{* *}$ & $\begin{array}{l}.13^{*} \\
*\end{array}$ & ${ }^{*} .01$ & $.29 * *$ & 1 & & & \\
\hline$\stackrel{\text { ト }}{>}$.Conscientiousness & $.21 * *$ & $.19 * *$ & $-.09 *$ & -.01 & .02 & .07 & -.07 & .20 & $.44^{* *}$ & 1 & & \\
\hline$\frac{ \pm}{\sigma} 11$. Neuroticism & $-.14 * *$ & -.03 & $.14^{* *}$ & .03 & .01 & .04 & $.09 *$ & $-.22 * *$ & $-.19 * *$ & $-.23 * *$ & 1 & \\
\hline $\begin{array}{l}\text { ㄷํㄴ } 12 . \text { Openness to } \\
\text { जै experience }\end{array}$ & $.17^{* *}$ & $.26 * *$ & .04 & .05 & $.11 * *$ & $\begin{array}{l}.17^{*} \\
*\end{array}$ & $* .03$ & $.50 * *$ & $.37 * *$ & $.36 * *$ & $-.12 * *$ & 1 \\
\hline 13. Negative valence & $-.17 * *$ & .01 & $.34^{* *}$ & -.03 & .08 & $\begin{array}{l}.11^{*} \\
*\end{array}$ & * $.11^{* *}$ & $-.28 * *$ & $-.41 * *$ & $-.25 * *$ & $.38 *$ & $-.09 * 1$ \\
\hline
\end{tabular}

$* \mathrm{p}<.05, * * \mathrm{p}<.01$ 
According to Table 1, extraversion had a significant positive relationship with the SNS use purposes of research, cooperation and content sharing and a negative significant relationship with the SNS use purpose of initiating communication. Another finding revealed that agreeableness had a significant positive relationship with the SNS use purposes of research, cooperation, establishing communication, maintaining communication and content sharing and a negative significant relationship with the SNS use purpose of initiating communication. Considering conscientiousness, it had a significant positive relationship with research and cooperation and a negative significant relationship with initiating communication. In addition, there was a positive relationship between neuroticism and initiating communication and entertainment and a negative relationship between neuroticism and research. Also, the results demonstrated openness to experience had a positive relationship with research, cooperation, maintaining communication and content sharing. Lastly, negative valence had a positive relationship with initiating communication, content sharing and entertainment and a negative relationship with research.

\section{Multi-Linear Regression Analyses}

For the purpose of examining the effects of the sub-dimensions of personality traits on SNS use purposes, multi-linear regression analysis was applied. Before the analysis of the data, the participants with outliers were excluded from the data set. According to the results of the analyses, the data demonstrated a normal distribution. The results of the multi-linear regression analysis regarding the sub-dimensions of personality are presented in tables.

Table 2 presents the results of multi-linear regression analysis regarding the personality traits' prediction of SNS use for the purpose of research.

Table 2. Multi-Linear Regression Analysis Regarding the Personality Traits' Prediction of SNS Use for the Purpose of Research

\begin{tabular}{llllllll}
\hline Variable & $\mathrm{B}$ & $\begin{array}{l}\text { Standard } \\
\text { Error }\end{array}$ & $\beta$ & $\mathrm{t}$ & $\mathrm{p}$ & Paired $\mathrm{r}$ & Partial $\mathrm{r}$ \\
\hline Constant & 11,823 & 2.060 & - & 5.740 & .000 & - & - \\
Extraversion & .003 & .033 & .005 & .102 & .919 &, 123 &, 004 \\
Agreeableness & .024 & .050 & .022 & .472 & .637 &, 165 &, 018 \\
Conscientiousness & .102 & .035 & .128 & 2.921 & .004 &, 210 &, 114 \\
$\begin{array}{l}\text { Neuroticism } \\
\text { Openness to }\end{array}$ & -.041 & .027 & -.064 & -1.532 & .126 &,- 144 &,- 060 \\
$\begin{array}{l}\text { experience } \\
\text { Negative valence }\end{array}$ & .099 & .049 & .096 & 2.027 & .043 &, 168 &, 079 \\
\cline { 1 - 2 } $\mathrm{R}=, 267$ & -.113 & .056 & -.090 & -1.998 & .046 &,- 165 &,- 078 \\
$\mathrm{~F}=8,344$ & $\mathrm{R}^{2}=, 071$ & & & & & & \\
\hline
\end{tabular}

The results in Table 2 show that the personality traits significantly predicted SNS use for the purpose of research $(F=8.34, p<.001)$. All the personality traits explained $7 \%$ of the variance. According to the standardized regression coefficient $(\beta)$, the relative order of predictor variables in terms of the purpose of research was as follows: Conscientiousness $(\beta=.128)$, openness to experience $(\beta=.96)$, negative valence $(\beta=-.090)$, neuroticism $(\beta=-.064)$, agreeableness $(\beta=.022)$ 
and extraversion $(\beta=.005)$. When the t-test results regarding the significance of the regression coefficients were examined, it was seen that the variables of conscientiousness and openness to experience were significant positive predictors of the purpose of research and that the variable of negative valence was a significant negative predictor of the purpose of research. These findings could be said to support the hypotheses of $\mathrm{H} 1, \mathrm{H} 2$ and $\mathrm{H} 4$ put forward in the present study.

Table 3 presents the results of multi-linear regression analysis regarding the personality traits' prediction of SNS use for the purpose of cooperation.

Table 3. Multi-Linear Regression Analysis Regarding the Personality Traits' Prediction of SNS Use of the Purpose of Cooperation

\begin{tabular}{|c|c|c|c|c|c|c|c|}
\hline Variable & $B$ & $\begin{array}{l}\text { Standard } \\
\text { error }\end{array}$ & $\beta$ & $\mathrm{t}$ & $p$ & Paired $r$ & Partial $r$ \\
\hline Constant & 3.766 & 3.826 & - & .984 & .325 & - & - \\
\hline Extraversion & -.021 & .062 & -.016 & -.347 & .729 & 110 &,- 014 \\
\hline Agreeableness & .260 & .093 & .129 & 2.799 & .005 & 196 & 109 \\
\hline Conscientiousness & .129 & .065 & .087 & 1.992 & .047 & 187 & 078 \\
\hline Neuroticism & -.006 & .050 & -.005 & -.123 & .903 &,- 031 &,- 005 \\
\hline $\begin{array}{l}\text { Openness to } \\
\text { experience }\end{array}$ & .378 & .091 & .194 & 4.149 & .000 & 257 & 160 \\
\hline Negative valence & .227 & .105 & .097 & 2.169 & .030 & 007 & ,085 \\
\hline$R=, 301$ & $R^{2}=, 090$ & & & & & & \\
\hline$F=10,813$ & $p=, 000$ & & & & & & \\
\hline
\end{tabular}

The results presented in Table 3 demonstrate that the personality traits significantly predicted SNS use for the purpose of cooperation $(F=10.81, p<.001)$. All the personality traits explained $9 \%$ of the variance. According to the standardized regression coefficient $(\beta)$, the relative order of the predictor variables in terms of the purpose of cooperation was as follows: openness to experience $(\beta=.194)$, agreeableness $(\beta=.129)$, negative valence $(\beta=.097)$, conscientiousness $(\beta=.087)$, extraversion $(\beta=-.016)$ and neuroticism $(\beta=-.005)$. When the $t$-test results regarding the significance of the regression coefficients were examined, it was seen that the variables of agreeableness, conscientiousness, openness to experience and negative valence were significant positive predictors of the purpose of cooperation. These findings support the hypotheses of $\mathrm{H} 1, \mathrm{H} 2, \mathrm{H} 3$ and $\mathrm{H} 4$ put forward in the present study.

Table 4 presents the results of multi-linear regression analysis regarding the personality traits' prediction of SNS use for the purpose of initiating communication

Table 4. Multi-Linear Regression Analysis Regarding the Personality Traits' Prediction of SNS Use for The Purpose of Initiating Communication

\begin{tabular}{lccccccc}
\hline Variable & $\mathrm{B}$ & $\begin{array}{c}\text { Standard } \\
\text { error }\end{array}$ & $\beta$ & $\mathrm{t}$ & $\mathrm{p}$ & Paired $r$ & Partial $r$ \\
\hline Constant & 2.826 & 2.278 & - & 1.241 & .215 & - & - \\
Extraversion & -.041 & .037 & -.049 & -1.117 & .264 &,- 093 &,- 044 \\
Agreeableness & .003 & .055 & .003 & .058 & .954 &,- 123 &, 002 \\
Conscientiousness & -.036 & .039 & -.040 & -.933 & .351 &,- 091 &,- 036 \\
\hline
\end{tabular}




\begin{tabular}{|c|c|c|c|c|c|c|c|}
\hline Neuroticism & .007 & .030 & .009 & .219 & .827 & 140 & 009 \\
\hline $\begin{array}{l}\text { Openness to } \\
\text { experience }\end{array}$ & .130 & .054 & .110 & 2.405 & .016 & ,042 & ,094 \\
\hline Negative valence & .461 & .062 & .324 & 7.399 & .000 & ,340 & 278 \\
\hline$R=, 352$ & $R^{2}=, 124$ & & & & & & \\
\hline$F=15,403$ & $p=, 000$ & & & & & & \\
\hline
\end{tabular}

The results in Table 4 demonstrated that the personality traits significantly predicted SNS use for the purpose of initiating communication $(F=15.40, p<.001)$. All the personality traits explained $12 \%$ of the variance. According to the standardized regression coefficient $(\beta)$, the relative order of the predictor variables in terms of the purpose of initiating communication was as follows: negative valence $(\beta=.324)$, openness to experience $(\beta=.110)$, extraversion $(\beta=-.049)$ conscientiousness $(\beta=-.040)$, neuroticism $(\beta=.009)$ and agreeableness $(\beta=.003)$. When the $t-$ test results regarding the significance of the regression coefficients were examined, it was seen that the variables of openness to experience and negative valence were significant positive predictors of the purpose of initiating communication. These findings support the hypotheses of $\mathrm{H} 2$ and $\mathrm{H} 4$ in the study.

Table 5 presents the results of multi-linear regression analysis regarding the personality traits' prediction of SNS use for the purpose of establishing communication.

Table 5. Multi-Linear Regression Analysis Regarding the Personality Traits' Prediction of SNS Use for The Purpose of Establishing Communication

\begin{tabular}{llllllll}
\hline Variable & $\mathrm{B}$ & $\begin{array}{l}\text { Standard } \\
\text { error }\end{array}$ & $\beta$ & $\mathrm{t}$ & $\mathrm{p}$ & Paired $\mathrm{r}$ & Partial $\mathrm{r}$ \\
\hline Constant & 5.682 & 1.746 & - & 3.254 & .001 & - & - \\
Extraversion & .023 & .028 & .038 & .815 & .416 &, 057 &, 032 \\
Agreeableness & .120 & .042 & .136 & 2.836 & .005 &, 112 &, 110 \\
Conscientiousness & -.043 & .030 & -.066 & -1.462 & .144 &,- 007 &,- 057 \\
Neuroticism & .030 & .023 & .055 & 1.297 & .195 &, 033 &, 051 \\
$\begin{array}{l}\text { Openness to } \\
\text { experience }\end{array}$ & .006 & .042 & .007 & .146 & .884 &, 047 &, 006 \\
Negative valence & -.005 & .048 & -.005 & -.112 & .911 &,- 034 &,- 004 \\
\cline { 1 - 2 } $\mathrm{R}=, 142$ & $\mathrm{R}^{2}=, 020$ & & & & & & \\
$\mathrm{~F}=2,231$ & $\mathrm{p}=, 039$ & & & & & & \\
\hline
\end{tabular}

The results in Table 5 revealed that the personality traits significantly predicted SNS use for the purpose of establishing communication $(F=2.231, p<.05)$. All the personality traits explained $2 \%$ of the variance. According to the standardized regression coefficient $(\beta)$, the relative order of the predictor variables in terms of the purpose of establishing communication was as follows: agreeableness $(\beta=.136)$, conscientiousness $(\beta=-.066)$, neuroticism $(\beta=.055)$, extraversion $(\beta=.038)$, openness to experience $(\beta=.007)$ and negative valence $(\beta=-.005)$. When the t-test results regarding the significance of the regression coefficients were examined, it was seen that the variable of agreeableness was a significant positive predictor of the purpose of establishing communication. These findings support the hypothesis of $\mathrm{H} 3$ put forward in the present study.

Table 6 presents the results of multi-linear regression analysis regarding the personality traits' prediction of SNS use for the purpose of maintaining communication. 
Table 6. Multi-Linear Regression Analysis Regarding the Personality Traits' Prediction of SNS Use for The Purpose of Maintaining Communication

\begin{tabular}{llllllll}
\hline Variable & $\mathrm{B}$ & $\begin{array}{l}\text { Standard } \\
\text { error }\end{array}$ & $\beta$ & $\mathrm{t}$ & $\mathrm{p}$ & Paired $\mathrm{r}$ & Partial $\mathrm{r}$ \\
\hline Constant & 6.122 & 3.103 & - & 1.973 & .049 & - & - \\
Extraversion & -.033 & .050 & -.030 & -.656 & .512 &, 021 &,- 026 \\
Agreeableness & .253 & .075 & .160 & 3.361 & .001 &, 113 &, 130 \\
Conscientiousness & -.057 & .052 & -.049 & -1.088 & .277 &, 021 &,- 043 \\
Neuroticism & -.019 & .041 & -.020 & -.462 & .644 &, 009 &,- 018 \\
$\begin{array}{l}\text { Openness to } \\
\text { experience }\end{array}$ & .151 & .074 & .098 & 2.039 & .042 &, 114 &, 080 \\
Negative valence & .254 & .085 & .137 & 2.990 & .003 &, 076 &, 116 \\
\cline { 2 - 2 } $\mathrm{R}=, 194$ & $\mathrm{R}=, 038$ & & & & & & \\
$\mathrm{~F}=4,272$ & $\mathrm{p}=, 000$ & & & & & & \\
\hline
\end{tabular}

The results in Table 6 revealed that the personality traits significantly predicted SNS use for the purpose of maintaining communication $(F=4.27, p<.001)$. All the personality traits explained $4 \%$ of the variance. According to the standardized regression coefficient $(\beta)$, the relative order of the predictor variables in terms of the purpose of maintaining communication was as follows: agreeableness $(\beta=.160)$, negative valence $(\beta=.137)$, openness to experience $(\beta=.098)$ conscientiousness $(\beta=-.049)$, extraversion $(\beta=-.030)$ and neuroticism $(\beta=-.020)$. When the t-test results regarding the significance of the regression coefficients were examined, it was seen that the variables of agreeableness, openness to experience and negative valence were significant positive predictors of the purpose of maintaining communication. These findings support the hypotheses of $\mathrm{H} 2, \mathrm{H} 3$ and $\mathrm{H} 4$ put forward in the study.

Table 7 presents the results of multi-linear regression analysis regarding the personality traits' prediction of SNS use for the purpose of content sharing.

Table 7. Multi-Linear Regression Analysis Regarding the Personality Traits' Prediction of SNS Use for The Purpose of Content Sharing

\begin{tabular}{llllllll}
\hline Variable & $\mathrm{B}$ & $\begin{array}{l}\text { Standard } \\
\text { error }\end{array}$ & $\beta$ & $\mathrm{t}$ & $\mathrm{p}$ & Paired $\mathrm{r}$ & Partial $\mathrm{r}$ \\
\hline Constant & -2.327 & 3.743 & - & -.622 & .534 & - & - \\
Extraversion & .046 & .060 & .035 & .759 & .448 &, 083 &, 030 \\
Agreeableness & .296 & .091 & .152 & 3.258 & .001 &, 128 &, 126 \\
Conscientiousness & .007 & .063 & .005 & .110 & .912 &, 071 &, 004 \\
Neuroticism & .018 & .049 & .016 & .376 & .707 &, 036 &, 015 \\
$\begin{array}{l}\text { Openness to } \\
\text { experience }\end{array}$ & .222 & .089 & .118 & 2.491 & .013 &, 174 &, 097 \\
Negative valence & .428 & .102 & .189 & 4.177 & .000 &, 111 &, 161 \\
\cline { 1 - 2 } $\mathrm{R}=, 255$ & $\mathrm{R}^{2}=, 065$ & & & & & & \\
$\mathrm{~F}=7,543$ & $\mathrm{p}=, 000$ & & & & & & \\
\hline
\end{tabular}

The results in Table 7 revealed that the personality traits significantly predicted SNS use for the purpose of content sharing $(\mathrm{F}=7.54, \mathrm{p}<.001)$. All the personality traits explained $6 \%$ of the variance. According to the standardized regression coefficient $(\beta)$, the relative order of the predictor variables in terms of the purpose of content sharing was as follows: negative valence 
$(\beta=.189)$, agreeableness $(\beta=.152)$, openness to experience $(\beta=.118)$, extraversion $(\beta=.035)$, neuroticism $(\beta=.016)$ and conscientiousness $(\beta=.005)$. When the t-test results regarding the significance of the regression coefficients were examined, it was seen that the variables of agreeableness, openness to experience and negative valence were significant positive predictors of the purpose of content sharing. These findings support the hypotheses of $\mathrm{H} 2, \mathrm{H} 3$ and $\mathrm{H} 4$ put forward in the study.

Table 8 presents the results of multi-linear regression analysis regarding the personality traits' prediction of SNS use for the purpose of entertainment.

Table 8. Multi-Linear Regression Analysis Regarding the Personality Traits' Prediction of SNS Use for The Purpose of Entertainment

\begin{tabular}{|c|c|c|c|c|c|c|c|}
\hline Variable & $B$ & $\begin{array}{l}\text { Standard } \\
\text { error }\end{array}$ & $\beta$ & $\mathrm{t}$ & $p$ & Paired $r$ & Partial $r$ \\
\hline Constant & 7.235 & 2.497 & - & 2.897 & .004 & - & - \\
\hline Extraversion & -.003 & .040 & -.003 & -.068 & .946 &,- 015 &,- 003 \\
\hline Agreeableness & .104 & .061 & .082 & 1.716 & .087 & ,006 & ,067 \\
\hline Conscientiousness & -.077 & .042 & -.082 & -1.821 & .069 &,- 068 &,- 071 \\
\hline Neuroticism & .034 & .033 & .044 & 1.030 & .303 & ,086 & 040 \\
\hline $\begin{array}{l}\text { Openness to } \\
\text { experience }\end{array}$ & .055 & .059 & .045 & .932 & .351 & ,029 & ,036 \\
\hline Negative valence & .168 & .068 & .114 & 2.464 & .014 & 114 & ,096 \\
\hline$R=, 156$ & $R^{2}=, 024$ & & & & & & \\
\hline$F=2,702$ & $p=, 013$ & & & & & & \\
\hline
\end{tabular}

The results in Table 8 revealed that the personality traits significantly predicted SNS use for the purpose of entertainment $(\mathrm{F}=2.70, \mathrm{p}<.05)$. All the personality traits explained $2 \%$ of the variance. According to the standardized regression coefficient $(\beta)$, the relative order of the predictor variables in terms of the purpose of entertainment was as follows: negative valence $(\beta=.114)$, agreeableness $(\beta=.082)$, conscientiousness $(\beta=-.082)$, openness to experience $(\beta=.045)$, neuroticism $(\beta=.044)$ and extraversion $(\beta=-.003)$. When the t-test results regarding the significance of the regression coefficients were examined, it was seen that the variable of negative valence was a significant positive predictor of the purpose of entertainment. These findings support the hypothesis of $\mathrm{H} 4$ in the study.

In the present study, the sub-dimensions of personality such as conscientiousness (H1), openness to experience $(\mathrm{H} 2)$, agreeableness $(\mathrm{H} 3)$, negative valence $(\mathrm{H} 4)$, extraversion $(\mathrm{H} 5)$ and neuroticism (H6) were initially thought to predict SNS use purposes. However, the research findings did not support the hypotheses of $\mathrm{H} 5$ and $\mathrm{H} 6$ though the findings supported the hypotheses of $\mathrm{H} 1, \mathrm{H} 2, \mathrm{H} 3$ and $\mathrm{H} 4$.

\section{Discussion and Conclusion}

According to the research findings, conscientiousness positively predicted the SNS use purpose of research. It is a well-known fact that conscientiousness is one of the most important dimensions in the context of education and learning (Wehrli, 2008). In addition, this personality trait is associated with educational performance and persistence (De Raad \& Schouwenburg, 1996). Therefore, in the present study, the preservice teachers with conscientiousness might 
have used SNSs more frequently for research purposes in their education process. In one study, Hughes et al. (2012) thought that the individuals used Twitter to search information in line with their future goals like getting informed about their future work or about their study and that use of Facebook to search for information could be an indicative of procrastination and a lack of selfdiscipline. As another finding obtained in the present study, conscientiousness positively predicted SNS use for the purpose of cooperation. In one other study, examining the relationship between teachers' self-efficacy and their effectiveness, Seghal (2015) found a moderate level of relationship between conscientiousness and cooperation. When viewed from a general perspective, the individuals with a high level of conscientiousness were more organized, planned and success-oriented (McCrea\&Costa, 2003; Funder, 2001). Good planning is an important step in technology integration (Liu \& Velazques-Bryant, 2003). In this respect, preservice teachers with a high level of conscientiousness could be more successful in integrating technology in educational environments in future (Perkmen, 2014).

In the present study, it was seen that openness to experience positively predicted the SNS use purpose of research. The results of other related studies demonstrated that there were positive relationships between openness to experience and SNS use for the purpose of seeking information (Hughes et al., 2012; Yılmaz \& Bilgin, 2017). It is pointed out that individuals with high levels of openness to experience are intellectually open to innovations and curious (Caspi et al., 2005). Therefore, in the present study, the preservice teachers with this type of personality were likely to use social networks to search information about their interests or studies. Another finding obtained in the present study revealed that openness to experience was a significant positive predictor of SNS use purposes such as cooperation, initiating communication, maintaining communication and content sharing. When the related literature is examined, it is seen that most researchers found a positive relationship between openness to experience and SNS use for the purpose of communication and cooperation (Correa et al., 2010; Dunaetz, 2008; Hughes, 2012; Muscannell \& Guadagno, 2012). In addition, Gosling et al. (2011), in their study with university students, found a positive relationship between openness to experience and the number of photos added and shared via SNSs.

It was found that agreeableness was a significant positive predictor of SNS use for the purpose of cooperation. Costa and McCrage (1992) pointed out that agreeableness reflected individuals' levels of maintaining and supporting interpersonal cooperation. This situation could explain the fact that the preservice teachers in the present study who had the personality trait of agreeableness used SNSs for the purpose of cooperation. Another finding obtained in the study was that agreeableness was a significant positive predictor of the purposes of establishing and maintaining communication. Seidman (2012) reported that agreeable undergraduate students were more likely to use Facebook to seek acceptance and maintain connection. In addition, other related studies revealed positive relationships between agreeableness and the time spent on various types of communication via SNSs (Ryan \& Xenos, 2011; Wilson et al., 2010), between agreeableness and making comments via SNSs (Wang et al., 2012).

It was found that negative valence acted as a significant negative predictor of SNS use for the purpose of research and as a significant positive predictor of the purposes of cooperation, initiating communication, maintaining communication, content sharing and entertainment. Negative valence, one of the personality types, refers to the negative, detrimental and even probably relentless image of a person (Durrett \& Trull, 2005). Individuals with a prominent personality trait of negative valence could be said to have low levels of self-worth and selfesteem (Gencoz \& Oncul, 2012; Durrett \& Trull, 2005) and to have negative self-assessment and negative self-attribution (Durrett \& Trull, 2005). When the related literature is examined, it is 
seen that there is no research examining the relationship between negative valence and SNS use and that SNS use is mostly associated with low self-esteem. Mehdizadeh (2007) reported that university students with low levels of self-esteem were involved in more online activities via SNSs. Another related study demonstrated that an increasing use of social media could lead to a decrease in university students' self-esteem (Jan, Soomro, \& Ahmad, 2017). In the present study, it was found that negative valence had a relationship with most of the SNS use purposes. This situation might be due to the fact that preservice teachers with negative valence, which is associated with low self-esteem, use SNSs more frequently and get involved in more activities. In general, it could be stated based on the results of the present study that the preservice teachers with negative valence did not use SNSs for the purpose of research but mostly for the purposes of communication, content sharing and entertainment.

In the present study, extraversion did not predict any SNS use purposes. Similarly, Hughes et al. (2011) did not find any significant relationship between extraversion and communicative features of SNSs. On the other hand, McElroy, Hendrickson, Townsend, and DeMarie (2007) revealed that extravert university students spent less time on Facebook as they preferred faceto-face communication more when compared to introvert individuals, while some other researchers reported that extravert individuals spent more time on SNSs (Gosling et al., 2011; Ryan \& Xenos, 2011; Wilson et al., 2010). In the present study, the finding that no relationship was found between extraversion and SNS use purposes could be explained with the fact that the extravert preservice teachers participating in the study preferred face-to-face communication to SNSs for socialization.

Lastly, neuroticism did not predict any SNS use purposes. In a study carried out by Muscanell and Guadagno (2012) with university students, the researchers did not find any significant relationship between neuroticism and SNS use. A similar result was also reported by Gosling et al. (2011) in their study. Hughes et al. (2012), who investigated whether there was a relationship between neuroticism and SNS use, reported that young neurotic individuals who were more social used Facebook more for social purposes. Moreover, researchers believe that individuals with high levels of neuroticism use the Internet to decrease feelings of loneliness and to create sense of belonging (Amichai-Hamburger \& Ben-Artzi, 2003; Butt \& Phillips, 2008; Correa et al., 2010).

\section{Recommendations}

As mentioned before, social network tools support educational activities by allowing interaction, cooperation, active participation and sharing information and sources. In addition, studies demonstrate that personality traits of preservice teachers might have influence on their motivation towards technology integration in educational environments (Perkmen, 2014). Therefore, it is recommended that both teacher educators and teacher training programs should consider individual differences in guiding preservice teachers to use social networks effectively in educational environments.

The research sample included in the present study was limited to preservice teachers only from a single university. SNSs are regarded as a reflection of social structures. For this reason, factors like cultural differences and socio-economic situations could have influence on humancomputer interaction in learning environments. In this respect, future studies to be conducted with different sample groups will make important contributions. In addition, the present study was based on quantitative findings. Supporting this research with qualitative studies in the 
future could provide more in-depth information in terms of revealing the causes of relationships between personality and SNS use.

\section{References}

Alan, A.K. \& Kabadayı, E.T. (2016). The effect of personal factors on social media usage of young consumers. Procedia - Social and Behavioral Sciences, 235, 595-602.

Amichai-Hamburger, Y. \& Ben-Artzi, E. (2003). Loneliness and Internet use. Computers in Human Behavior, 19(1), 71-80.

Amichai-Hamburger, Y. \& Vinitzky, G. (2010). Social network use and personality. Computers in Human Behavior, 26, 1289-1295.

Atabek, O. (2012). Preservice teachers' personality, motives, motivation, and attitudes associated with the use of social network services: Facebook case. In C.D. Maddux \& D. Gibson (Eds.), Research highlights in technology and teacher education 2012 (pp. 109116). SITE.

Avcilar, M. Y., \& Demirgunes, B. K. (2016). Analyzing the effects of personality traits on motivations for using social media. Journal of Management Marketing and Logistics, 3(3), 251-271.

Boyd, D.M., \& Ellison, N. B. (2007). Social network sites: Definition, history, and scholarship. Journal of Computer-Mediated Communication, 13(1), 210-230.

Butt, S. \& Phillips, J. G. (2008). Personality and self-reported mobile phone use. Computers in Human Behavior, 24(2), 346-360.

Buyukozturk, S., Cakmak, E. K., Akgun, Ö. A., Karadeniz, S. \& Demirel, F. (2010). Bilimsel arastirma yontemleri. Ankara: PegemA.

Caspi, A., Roberts, B. W., \& Shiner, R. L. (2005). Personality development: Stability and change. Annual Reviews of Psychology, 56, 453-484.

Correa, T., Hinsley, A. W., \& De Zuniga, H. G. (2010). Who interacts on the Web?: The intersection of users' personality and social media use. Computers in Human Behavior, 26(2), 247-253.

Costa, P. T. \& McCrae, R. R. (1992). NEO PI-R. Professional manual. Odessa, FL: Psychological Assessment Resources.

Cetin, E. (2009). Sosyal iletisim aglari ve genclik: Facebook ornegi. Uluslararasi Davraz Kongresi Bildiri Kitabi (ss. 1094-1105). Isparta: Suleyman Demirel Universitesi.

Dal, N.E., \& Dal, V. (2014). Kisilik ozellikleri ve sosyal ag sitesi kullanim aliskanliklari: Universite ogrencileri uzerine bir arastirma. Mehmet Akif Ersoy Universitesi Sosyal Bilimler Enstitusu Dergisi, 6(11), 144-162.

De Raad, B. \& Schouwenburg, H.C. (1996). Personality in learning and education: A review. European Journal of Personality, 10, 303-336.

Dunaetz, D. (2008). A meta-analysis of the relationship between personality and preferred conflict style. Retrieved on 15 May 2019 from SSRN: https://ssrn.com/abstract=3227529 or http://dx.doi.org/10.2139/ssrn.3227529. 
Durrett, C. \& Trull, T.J. (2005). An evaluation of evaluative personality terms: a comparison of the big seven and five-factor model in predicting psychopathology. Psychological Assessment, 17(3), 359-368.

Ehrenberg, A., Juckes, S., White, K. M., \& Walsh, S. P. (2008). Personality and self-esteem as predictors of young people's technology use. Cyberpsychology \& Behavior, 11(6), 739741.

Ellison, N. B., Steinfield, C., \& Lampe, C. (2007). The benefits of Facebook "friends:" Social capital and college students' use of online social network sites. Journal of ComputerMediated Communication, 12(4), 1143-1168.

Funder, D. C. (2001). Personality. Annual Reviews of Psychology. 52, 197-221.

Gencoz, T. \& Oncul, O. (2012). Examination of personality characteristics in a Turkish sample: Development of basic personality traits inventory. The Journal of General Psychology. 139(3), 194-216.

Goldberg, L.R. (1990). An alternative description of personality: the big-five factor structure. Journal of Personality and Social Psychology, 59(6), 1216-1229.

Gosling, S. D., Augustine, A. A., Vazire, S., Holtzman, N., \& Gaddis, S. (2011). Manifestations of personality in online social networks: Self-reported Facebook-related behaviors and observable profile information. Cyberpsychology, Behavior, and Social Networking, 14(9), 483-488.

Hamburger, Y. A. \& Ben-Artzi, E. (2000). The relationship between extraversion and neuroticism and the different uses of the Internet. Computers in Human Behavior, 16(4), 441-449.

Hughes, D. J., Rowe, M., Batey, M., \& Lee, A. (2012). A tale of two sites: Twitter vs. Facebook and the personality predictors of social media usage. Computers in Human Behavior, 28(2), 561-569.

Isbulan, O. (2011). Opinions of university graduates about social networks according to their personal characteristics. The Turkish Online Journal of Educational Technology, 10(2), 184-189.

Jan, M.A., Soomro, S., \& Ahmad, N. (2017). Impact of social media on self-esteem. European Scientific Journal, 13, 329-341.

Jones, S. \& Fox, S. (2009). Generations online in 2009. Pew Internet and American Life Project. Retrieved on 15 May 2019 form http://www.pewinternet.org/2009/01/28/generationsonline-in-2009/

Karasar, N. (2005). Bilimsel arastirma yontemi. (15. baski). Ankara: Nobel.

Kemp, S. (2018). Digital in 2018: World's internet users pass the 4 billion mark. Retrieved on 15 May 2019 from https://wearesocial.com/sg/blog/2018/01/globaldigital-report-2018.

Kim, W., Jeong, O. R., \& Lee, S. W. (2010). On social Web sites. Information Systems, 35(2), 215-236.

Kumar, S. \& Vigil, K. (2011). The net generation as preservice teachers: Transferring familiarity with new technologies to educational environments. Journal of Digital Learning in Teacher Education, 27(4), 144-153. 
Lee, C.C., Chou, S.T.H., \& Huang, Y.R. (2014). A study on personality traits and social media fatigue-example of Facebook users. Lecture Notes on Information Theory, 2(3), 249-253.

Lin, M.F.G., Hoffman, E.S., \& Borengasser, C. (2013). Is social media too social for class? A case study of Twitter use. TechTrends, 57(2), 39-45.

Liu, L. \& Velasquez-Bryanyt, N. (2003). An information technology integration system and its life cycle: What is missing? Computers in the Schools, 20(1-2), 93-106.

Mazman, S. G. \& Usluel, Y. K. (2010). Modeling educational usage of Facebook. Computers \& Education, 55(2), 444-453.

Mccrea, R. R. \& Costa, P. T. (2003). Facts and theories of adult development. Personality in adulthood a five-factor theory perspective. (pp. 1-19). New York: The Guilford Press.

McElroy, J., Hendrickson, A., Townsend, A., \& DeMarie, S. (2007). Dispositional factors in Internet use: Personality versus cognitive style. MIS Quarterly, 31(4), 809-820.

Mehdizadeh, S. (2010). Self-presentation 2.0: Narcissism and self-esteem on Facebook. Cyberpsychology, Behavior, and Social Networking, 13(4), 357-64.

Muscanell, N. L. \& Guadagno, R. E. (2012). Make new friends or keep the old: Gender and personality differences in social networking use. Computers in Human Behavior, 28, 107112.

O'Reilly, T., \& Milstein, S. (2009). The Twitter book. Sebastopol: O'Reilly Media.

Pagani, M., Hofacker, C.F., \& Goldsmith, R.E. (2011). The influence of personality on active and passive use of social networking sites. Psychology and Marketing, 28, 441-456.

Perkmen, S. (2014). The role of personality and school climate on pre-service teachers' motivation towards technology integration in education. E-journal of New World Sciences Academy- Education Sciences, 9(4), 380-393.

Ranieri, M., Manca, S., \& Fini, A. (2012). Why (and how) do teachers engage in social networks? An exploratory study of professional use of Facebook and its implications for lifelong learning. British Journal of Educational Technology, 43(5), 754-769.

Ross, C., Orr, E. S., Sisic, M., Arseneault, J. M., Simmering, M. G., \& Orr, R. R. (2009). Personality and motivations associated with Facebook use. Computers in Human Behavior, 25(2), 578-586.

Ryan, T. \& Xenos, S. (2011). Who uses Facebook? An investigation into the relationship between the Big Five, shyness, narcissism, loneliness, and Facebook usage. Computers in Human Behaviors, 27, 1658-1664.

Seghal, P (2015). Exploring the relationship between teacher self-efficacy and teacher effectiveness: role of personality, collaboration and principal leadership (Unpublished doctoral dissertation). Indian Institute of Management Indore, India.

Seidman, G. (2013). Self-presentation and belonging on Facebook: How personality influences social media use and motivations. Personality and Individual Differences, 54(3), 402-407.

Sendurur, P., Sendurur, E., \& Yilmaz, R. (2015). Examination of the social network sites usage patterns of pre-service teachers. Computers in Human Behavior, 51, 188-194.

Staines, Z. \& Lauchs, M. (2013). Students' engagement with Facebook in a university undergraduate policing unit. Australian Journal of Educational Technology, 29(6), 792805. 
Usluel, Y. K., Demir, O., \& Cinar, M. (2014). Sosyal aglarin kullanim amaclari olcegi. Egitim Teknolojileri Arastirma Dergisi, 5(2), 1-18.

Wang J.-L., Jackson, L.A., Zhang, D.-J., \& Su, Z.-Q. (2012). The relationships among the Big Five Personality factors, self-esteem, narcissism, and sensation-seeking to Chinese University students' uses of social networking sites (SNSs). Computers in Human Behavior, 28 (6), 2313-2319.

Wehrli, S. (2008). Personality on social network sites: An application of the five factor model. Zurich: ETH Sociology (Working Paper No. 7).

Wilson, K., Fornasier, S., \& White, K. M. (2010). Psychological predictors of young adults' use of social networking sites. Cyberpsychology, Behavior, and Social Networking, 13(2), 173177.

Wolfradt, U. \& Doll, J. (2001). Motives of adolescents to use the Internet as a function of personality traits, personal and social factors. Journal of Educational Computing Research, 24(1), 13-27.

Yilmaz, A. \& Bilgin, M. (2017). The relationship between social network usage and some personality traits. International Journal of Human Sciences. 14(3), 2219-2243.

Yildirim, A. \& Simsek, H. (2006). Sosyal bilimlerde nitel arastirma yontemleri. Ankara: Seckin.

Zywica, J. \& Danowski, J. (2008). The faces of Facebookers: Investigating social enhancement and social compensation hypotheses. Journal of Computer-Mediated Communication, 14(1), 1-34.

Correspondence: Ferit Karakoyun, Ph.D., Department of Computer Education and Instructional Technologies, Ziya Gokalp Faculty of Education, Dicle University, Diyarbakir, Turkey 